\title{
Correlation of Minimum Apparent Diffusion Coefficient and Maximum Standardized Uptake Value of the Primary Tumor with Clinicopathologic Characteristics in Endometrial Cancer
}

\author{
Endometrium Kanserinde Primer Tümöre Ait Minimum Görünen Difüzyon Katsayısı ve \\ Maksimum Standardize Tutulum Değerleri ile Klinikopatolojik Özelliklerin Illişkisi
}

\author{
Evrim Sürer Budakl, Tayfun Toptaş2, Funda Aydın³, Ali Ozan Öner4, Can Çevikol5, Tayup Şimşek² \\ I Antalya Training and Research Hospital, Clinic of Nuclear Medicine, Antalya, Turkey \\ 2Akdeniz University Faculty of Medicine, Department of Gynecologic Oncological Surgery, Antalya, Turkey \\ ${ }^{3}$ Akdeniz University Faculty of Medicine, Department of Nuclear Medicine, Antalya, Turkey \\ ${ }^{4}$ Afyon Kocatepe University Faculty of Medicine, Department of Nuclear Medicine, Afyonkarahisar, Turkey \\ ${ }^{5}$ Akdeniz University Faculty of Medicine, Department of Radiology, Antalya, Turkey
}

\begin{abstract}
Objective: To explore the correlation of the primary tumor's maximum standardized uptake value (SUV $\left.V_{\max }\right)$ and minimum apparent diffusion coefficient $\left(A D C_{\min }\right)$ with clinicopathologic features, and to determine their predictive power in endometrial cancer (EC).

Methods: A total of 45 patients who had undergonestaging surgery after a preoperative evaluation with $18 \mathrm{~F}$-fluorodeoxyglucose (FDG) positron emission tomography/computerized tomography (PET/CT) and diffusion-weighted magnetic resonance imaging (DW-MRI) were included in a prospective case-series study with planned data collection. Multiple linear regression analysis was used to determine the correlations between the study variables.

Results: The mean $A D C_{\min }$ and $S U V_{\max }$ values were determined as $0.72 \pm 0.22$ and $16.54 \pm 8.73$, respectively. A univariate analysis identified age, myometrial invasion (MI) and lymphovascular space involvement (LVSI) as the potential factors associated with $A D C_{\min }$ while it identified age, stage, tumor size, MI, LVSI and number of metastatic lymph nodes as the potential variables correlated to $S U V_{\text {max }}$. In multivariate analysis, on the other hand, MI was the only significant variable that correlated with $A D C_{\min }(p=0.007)$ and $S U V_{\max }(p=0.024)$. Deep MI was best predicted by an $A D C_{\min }$ cutoff value of $\leq 0.77$

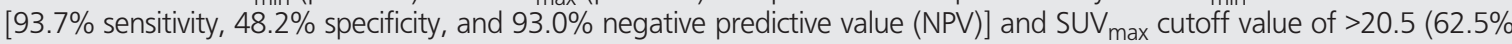
sensitivity, $86.2 \%$ specificity, and $81.0 \% \mathrm{NPV})$; however, the two diagnostic tests were not significantly different $(p=0.266)$. Conclusion: Among clinicopathologic features, only MI was independently correlated with $S_{U} V_{\max }$ and $A D C_{\min }$. However, the routine use of $18 \mathrm{~F}-F D G$ PET/CT or DW-MRI cannot be recommended at the moment due to less than ideal predictive performances of both parameters.
\end{abstract}

Keywords: Endometrial cancer, maximum standardized uptake value, minimum apparent diffusion coefficient

Address for Correspondence: Funda Aydın MD, Akdeniz University Faculty of Medicine, Department of Nuclear Medicine, Antalya, Turkey Phone: +90 5326380654 E-mail: afunda@akdeniz.edu.tr Received: 30.10.2016 Accepted: 09.01.2017 


\section{Öz}

Amaç: Endometrium kanserinde (EK) primer tümörün maksimum standardize tutulum değeri $\left(S U V_{\text {maks }}\right)$ ve minimum görünen difüzyon katsayısının $\left(A D C_{\text {min }}\right.$ ) klinikopatolojik özellikler ile olan ilişkisini araştırmak ve bunların öngörü gücünü belirlemektir.

Yöntem: 18F-fluorodeoksiglukoz (FDG) pozitron emisyon tomografisi/bilgisayarlı tomografi (PET/BT) ve difüzyon ağırlıklımanyetik rezonans görüntüleme (DA-MRG) ile preoperatif değerlendirmeyi takiben evreleme cerrahisi yapılan toplamda 45 hasta, planlı veri toplama yapılan prospektif bir olgu serisine dahil edildiler. Çalışma verileri arasındaki ilişkiler çoklu doğrusal regresyon analizi ile araştııılı.

Bulgular: Ortalama $A D C_{\text {min }}$ ve $S U V_{\text {maks }}$ sırasıyla $0,72 \pm 0,22$ ve $16,54 \pm 8,73$ olarak bulundu. Tek değişkenli analizde yaş, myometriyal invazyon (Mi) ve lenfovasküler alan tutulumu (LVAT) $A D C_{\text {min }}$ ile ilişkili potansiyel faktörler olarak bulunurken, yaş, evre, tümör büyüklüğü, LVAT ve metastatik lenf düğümlerinin sayısı SUV maks ile ilişkili potansiyel değişkenler olarak tespit edildiler. Diğer taraftan, çok değişkenli analizde Mi, $A D C_{\text {min }}(p=0,007)$ ve $S_{U V}$ maks $(p=0,024)$ ile ilişkili tek anlamlı değişkendi. Derin Mi en iyi, $\leq 0,77^{\prime}$ lik [\%93,7 duyarlıı, \%48,2 özgüllük ve \%93,0 negatif öngörü değeri (NPD)] bir ADC min kesim değeri ve $>20,5^{\prime}$ lik (\%62,5 duyarlılık, \%86,2 özgüllük ve \%81,0 NPD) bir SUV maks kesim değeri ile öngörülebiliyordu. Ne var ki, her iki tanısal test birbirlerinden anlamlı şekilde farklı değildi $(p=0,266)$.

Sonuç: Klinikopatolojik özelliklerden yalnızca Mi bağımsız ve anlamlı şekilde $S U V_{\text {maks }}$ ve $A D C_{\text {min }}$ ile ilişkiliydi. Ne var ki, her iki parametrenin ideal olmayan öngörü performansları nedeniyle 18F-FDG PET/BT veya DA-MRG'nin rutin kullanımı şu noktada önerilemez.

Anahtar kelimeler: Endometrium kanseri, maksimum standardize tutulum değeri, minimum görünen difüzyon katsayısı

\section{Introduction}

Endometrial cancer (EC) is the most common gynecologic malignancy in developed countries (1). The majority of patients present with disease limited to the uterus at the time of diagnosis, which leads to a generally high survival rate (2). Unfortunately, it has been reported that deaths from EC have increased over the past two decades, probably due to underestimation of actual tumor spread and increased rate of high-risk histology (3).

$E C$ is staged surgically using the International Federation of Gynecology and Obstetrics (FIGO) and American Joint Committee on Cancer staging systems $(4,5)$. While total hysterectomy and bilateral salpingo-oophorectomy ( $\mathrm{TH} /$ $\mathrm{BSO}$ ) is the mainstay treatment of uterine-confined disease, a comprehensive staging surgery including systematic lymphadenectomy allows for assessing the true extent of disease and the need for adjuvant therapy (6). Nevertheless, a systematic lymphadenectomy leads to a doubling of the complication rate (7). Besides, there are two randomized controlled trials demonstrating no survival benefit for lymphadenectomy especially in patients with presumed uterine-confined disease $(8,9)$.

According to the widely agreed view, a systematic lymphadenectomy may be omitted in selected patients considered to be at low-risk for extrauterine spread, without an unfavorable impact on disease prognosis. The most used criteria for defining low-risk patients are based on preoperative and intraoperative pathologic findings including well or moderately differentiated histology, tumor size less than $2 \mathrm{~cm}$, and myometrial invasion (MI) less than $50 \%(10)$. However, accurate identification of this group of patients may be somewhat problematic due to the variability in tumor grade and depth of $\mathrm{MI}$ on final pathologic examination (11).

The role of preoperative imaging for predicting tumor characteristics in patients with EC has been established by several studies, using different modalities $(12,13,14)$. Diffusion-weighted magnetic resonance imaging (DWMRI) and 18F-fluorodeoxyglucose (FDG) positron emission tomography combined with computed tomography (PET/ $\mathrm{CT}$ ) are the two imaging techniques that stood out from the others with their capability to provide metabolic and functional information regarding tumor tissue properties, in addition to anatomic information. Minimum apparent diffusion coefficient value $\left(A D C_{\min }\right)$ derived from $D W$ $M R I$ and maximum standardized uptake value $\left(S \cup V_{\max }\right)$ derived from 18F-FDG PET/CT are semi-quantitative imaging biomarkers which have been suggested to be of value in estimation of tumor behavior, as well as disease prognosis $(13,14)$. However, the clinical data regarding direct comparison of both biomarkers in preoperative evaluation of EC patients are sparse, and the routine use of them remains controversial.

In the current study, we aimed to investigate relationships of $S U V_{\max }$ and $A D C_{\min }$ of the primary tumor to clinicopathologic features, and to compare their predictive ability in patients with EC.

\section{Materials and Methods}

This prospective case-series with planned data collection enrolled consecutive patients with EC, who underwent primary staging surgery following a preoperative evaluation with 18F-FDG PET/CT and DW-MRI between May 2012 and December 2014. All imaging studies were performed 
within two weeks before the day of surgery, and all patients provided written informed consent.

Radiologic, pathologic and clinical data including age at surgery, $A D C_{\min }$ and $S U V_{\max }$ of the primary tumor, date and extent of the surgical procedure, number of lymph nodes (LNs) removed, stage of the disease, tumor histotype, tumor grade, tumor size, depth of myometrial invasion, lymphovascular space involvement (LVSI), cervical invasion, adnexal invasion, LN involvement, number of metastatic LNs, adjuvant therapy, disease status after primary therapy, disease recurrence, survival status, and the date of the last follow-up were recorded for all patients, following the The study were approved by the Akdeniz University of Local Ethics Committee (Protocol number: 23.12.2015; 386).

Patients with uterine sarcoma, primary synchronous malignancy, insufficient data, or that received radiotherapy, chemotherapy, or hormonal therapy as primary or neoadjuvant therapy were excluded.

\section{Positron Emission Tomography/Computerized Tomography Technique and Image Analysis}

Patients were requested to fast for at least six hours before imaging, and a venous blood glucose level below $200 \mathrm{mg} /$ $\mathrm{dL}$ was ensured. An oral contrast agent was administered to all patients prior to scanning. In order to facilitate urinary excretion, they were asked to drink $500 \mathrm{ml}$ of water and to void just before the acquisition. A whole body acquisition using integrated PET/CT scanner (Biograph 16 LSO; Siemens, Erlangen, Germany) was performed 45 to 60 minutes after intravenous administration of 18F-FDG (0.16 $\mathrm{mCi} / \mathrm{kg}$ ). A CT scan (slice thickness, $3 \mathrm{~mm}$; peak voltage, $120 \mathrm{kV}$; tube current, $110 \mathrm{~mA} / \mathrm{s}$ ) was performed, and used for anatomical localization and calculation of attenuation correction. The PET data were acquired from the vertex to the upper thigh, and the acquisition time for PET was three minutes per bed position. Attenuation-corrected PET, CT and fusion PET/CT images were interpreted by experienced nuclear medicine specialists. The $S U V_{\max }$ of the primary tumor was measured with a region of interest (ROI) technique. The measurements were performed in correlation with CT images while limiting the area of activity precisely and minimalizing the partial volume effect. Because of the close location to the bladder, it was important to separate the primary tumor and bladder activity in order to avoid incorrect measurements. From ROIs delineated on successive sections, the greatest $S U V_{\text {max }}$ was noted. SUV $\max$ values were automatically provided by a computer-assisted software program and they were calculated using the standard formula.

\section{Diffusion-Weighted Magnetic Resonance Imaging Technique and Image Analysis}

MRI examinations were performed using a 1.5 Tesla MRI scanner (Avanto; Siemens, Erlangen, Germany). The imaging protocol included: T2-weighted (T2W) fast-spin- echo (FSE) imaging in the sagittal and axial planes; FSE T1weighted (T1W) imaging in the axial plane; fat-saturated FSE T2W imaging in the coronal plane; and DW imaging in the same sagittal plane (repetition time, 6100 msec; echo time, $88 \mathrm{msec}$; flip angle, $90^{\circ}$; field of view, $241 \times 329$ $\mathrm{mm}$; slice thickness, $4 \mathrm{~mm}$; interslice gap, $0.8 \mathrm{~mm}$; matrix, 240x328; number of excitations, 5). The b-values of the diffusion sensitizing gradient were 50, 400 and $800 \mathrm{sec} /$ $\mathrm{mm}^{2}$. Post-contrast fat-saturated T1W sagittal and axial images were also obtained. Assessment of the images was performed by an experienced radiologist. The presence and the size of the endometrial lesion and its signal intensity relative to that of the adjacent myometrium were evaluated on T2W and DW images with a b-value of 800 $\mathrm{sec} / \mathrm{mm}^{2}$. ADC maps were generated automatically, and the measurements were performed by placing a ROI over the endometrial lesion with paying attention not to include areas of necrosis.

\section{Surgical Procedures, Adjuvant Therapy and Follow-up}

All patients underwent a staging surgery including at least $\mathrm{TH} / \mathrm{BSO}$, pelvic lymphadenectomy, omental biopsy, and peritoneal cytology. The pelvic lymphadenectomy consisted of complete removal of the LNs from the internal iliac, external iliac, obturatory and common iliac regions. A paraaortic $L N$ dissection up to the renal vessels was added to the staging procedure in the presence of any of the followings:

1) Non-endometrioid or grade 2-3 endometrioid histology on preoperative biopsy,

2) $\mathrm{Ml}$ greater than $50 \%$ on intraoperative frozen-section examination. All procedures were performed by two experienced gynecologic oncologists.

Tumor grading was conducted according to that of the World Health Organization (15), and staging was classified using the $\mathrm{FIGO}_{2009}$ system (4). Non-endometrioid histotypes were considered grade 3 tumors. According to institutional practice, age $(>50 \mathrm{yr})$, positive LVSI, tumor size $(>2 \mathrm{~cm})$ and lower uterine segment involvement were considered potential adverse risk factors. Adjuvant therapy strategy was as follows: Observation for stage 1A-grade 1 disease with no adverse risk factors; brachytherapy alone for stage 1A-grade 1 disease with one of the risk factors, stage 1A-grade 2-3 disease with no risk factors and stage 1B-grade 1-2 disease with no risk factors; external beam pelvic radiotherapy for stage 1A-grade 2-3 disease with one of the risk factors, stage 1B-grade 1-2 disease with one of the risk factors, stage 1B-grade 3 disease and stage 2 disease; chemotherapy plus external beam radiotherapy for stage 3 disease; and chemotherapy alone for stage $4 \mathrm{~B}$ disease. The chemotherapy regimen included six cycles of paclitaxel $175 \mathrm{mg} / \mathrm{m}^{2}$ plus carboplatin dosed at an area under the curve (AUC) of 5 to 6.

The surveillance practice was to follow-up patients who achieved a complete clinical remission after primary 
therapy every three months for two years, every six months for the next three years, and then annually. Recurrence was defined as any documented relapse of the tumor, either systemically or locally, after a disease-free interval of more than three months.

\section{Statistical Analysis}

All analyses were performed using IBM SPSS Statistics 20 software (SPSS/IBM, Chicago, IL, USA). Binary variables were reported as counts and percentages; continuous variables were expressed as mean, standard deviation, median, and range. A multiple linear regression analysis was performed to demonstrate correlation among variables of interest. All variables were separately evaluated by a univariate analysis using the Mann-Whitney $U$ test and Spearman's rank correlation coefficients ( $r$ value). Variables with a $p$ value $<0.05$ in the univariate analysis were selected and included in the multivariate analysis.

To define the diagnostic threshold values of $A D C_{\text {min }}$ and $S_{\text {SUax }}$, a receiver operating characteristic (ROC) curve analysis was performed by plotting every possible cutoff score's sensitivity on the y-axis against 1-specificity on the $x$-axis. The Youden index was calculated to choose the optimal cutoff values (16). For the ROC curve, the point with the largest sum of specificity and sensitivity was chosen as a threshold. In presenting the results, sensitivity, specificity, positive predictive value (PPV), and negative predictive value (NPV) were all reported. The AUCs of ROC curves and their 95\% confidence intervals (Cl) were compared using the method of DeLong et al. (17).

\section{Results}

A total of 45 patients were enrolled in the analysis. Table 1 presents the characteristics of patients. The mean age was $57.11 \pm 11.12$ years. The mean $A D C_{\min }$ and $S U V_{\max }$ of the primary tumor were $0.72 \pm 0.22$ and $16.54 \pm 8.73$, respectively. The majority of patients (73.3\%) had combined pelvic and paraaortic lymphadenectomy. The median number of pelvic LNs removed, paraaortic LNs removed, and total LNs removed (pelvic and paraaortic) were 28, 23, and 44, respectively. The distribution of the surgical stages of patients was as follows; stage $1 \mathrm{~A} 21$ patients $(46.7 \%)$, stage $1 \mathrm{~B}$ seven patients $(15.6 \%)$, stage 2 six patients $(13.3 \%)$, stage $3 A$ three patients $(6.7 \%)$, stage $3 \mathrm{C}$ six patients (13.3\%), and stage $4 \mathrm{~B}$ two patients $(4.4 \%)$. Most of the patients (77.8\%) had endometrioid histology. Deep $\mathrm{MI}\left(\geq \frac{1}{2}\right)$ was observed in $35.5 \%$ of the patients, LVSI in $28.9 \%$, cervical invasion in $31.1 \%$, adnexal invasion in $13.3 \%$, and LN metastasis in 17.8\%. During the median follow-up period of 20 months (range, 7.5-30.5 months), six patients (13.3\%) experienced disease recurrence with a median time to recurrence of 6 months (range, 4.5-15.5). Three examples of such cases are shown in Figure 1, 2, 3. The results of multiple linear regression analysis were summarized in Table 2. In univariate analysis, while
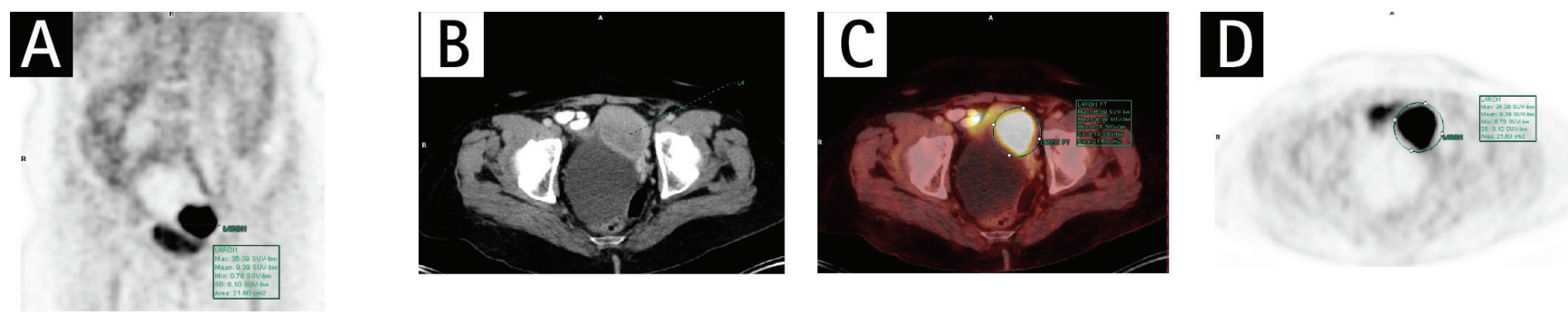

Figure 1. Maximum standardized uptake value of the primary tumor was measured 35,39. Endometrioid type endometrial carcinoma (grade 2 , International Federation of Gynecology and Obstetrics stage 3A). A) Maximum intensity projection image. B) Transaxial computed tomography image. C) Transaxial positron emission tomography+computed tomography fusion image. D) Transaxial positron emission tomography image of the primary tumor
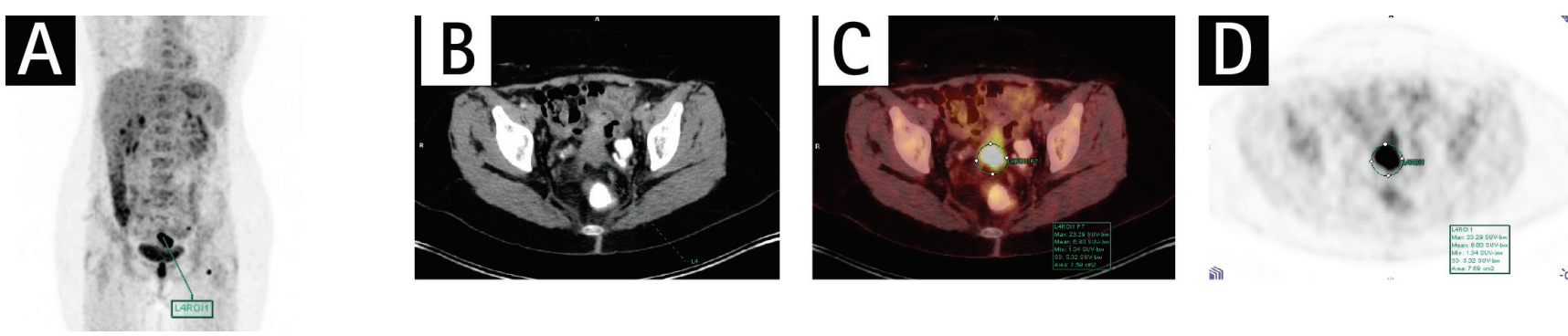

Figure 2. Maximum standardized uptake value of the primary tumor was measured 23,29. Non-endometrioid type (serous) endometrial carcinoma (grade 3, International Federation of Gynecology and Obstetrics stage 3C). A) Maximum intensity projection image. B) Transaxial computed tomography image. C) Transaxial positron emission tomography+computed tomography fusion image. D) Transaxial positron emission tomography image of the primary tumor 
Table 1. Characteristics of patients

\section{Variables}

Age at surgery, mean $\pm S D$, [median (range)], y

$A D C_{\text {min }}$ of the primary tumor, mean $\pm S D$, [median (range)]

$\mathrm{SUV}_{\max }$ of the primary tumor, mean $\pm \mathrm{SD}$, [median (range)]

Lymphadenectomy, n (\%)

Pelvic alone

Pelvic and paraaortic

No. of pelvic LNs removed, mean \pm SD, [median (range)]

No. of paraaortic $L$ Ns removed, mean $\pm S D$, [median (range)]

No. of total LNs removed, mean $\pm S D$, [median (range)]

FIGO stage, $n(\%)$

$1 \mathrm{~A}$

$1 \mathrm{~B}$

2

$3 \mathrm{~A}$

$3 C$

$4 \mathrm{~B}$

Histological type, n (\%)

Endometrioid

Non-endometrioid

Grade, n (\%)

1

2

3

Tumor size, mean $\pm \mathrm{SD}$, [median (range)], $\mathrm{cm}$

Deep myometrial invasion ( $\geq 1 / 2), n(\%)$

Lymphovascular space invasion, $\mathrm{n}(\%)$

Cervical invasion, $\mathrm{n}(\%)$

Adnexal invasion, $\mathrm{n}(\%)$

$\mathrm{LN}$ metastasis, $\mathrm{n}(\%)$

No. of metastatic LNs, mean $\pm S D$, [median (range)]

Adjuvant therapy, n (\%)

$$
\text { No adjuvant }
$$

Brachytherapy alone

External beam radiotherapy + /- brachytherapy

Chemotherapy plus external beam radiotherapy +/- brachytherapy

Chemotherapy alone

Recurrence, $n$ (\%)

Median time to recurrence $(95 \% \mathrm{Cl})$, months

Survival status, $\mathrm{n}(\%)$

Alive with no evidence of disease

Alive with disease

Dead of disease

Median follow-up time $(95 \% \mathrm{Cl})$, months

\section{Values}

$57.11 \pm 11.12,[56(27-84)]$

$0.72 \pm 0.22,[0.65(0.41-1.24)]$

$16.54 \pm 8.73,15[(5-35.39)]$

$12(26.7)$

$33(73.3)$

$27.25 \pm 7.74,[28(11-49)]$

$23.76 \pm 10.38,[23(10-43)]$

$44.98 \pm 16.25,[44(16-79)]$

$21(46.7)$

$7(15.6)$

$6(13.3)$

$3(6.7)$

$6(13.3)$

2 (4.4)

$35(77.8)$

$10(22.2)$

$22(48.9)$

$11(24.4)$

$12(26.7)$

$3.54 \pm 1.92$, [3 (0.35-8.30)]

16 (35.5)

13 (28.9)

14 (31.1)

$6(13.3)$

$8(17.8)$

1士2.61, [0 (0-11)]

15 (33.3)

$8(17.8)$

$11(24.4)$

$9(20.0)$

$2(4.4)$

$6(13.3)$

$6(4.5-15.5)$

39 (86.6)

$3(6.7)$

$3(6.7)$

$20.5(7.5-30.5)$

SD: Standard deviation, ADC $_{\text {min }}$ : Minimum apparent diffusion coefficient, SUV ${ }_{\text {max }}$ Maximum standardized uptake value, LN: Lymph node, FIGO: International Federation of Gynecology and Obstetrics, Cl: Confidential interval 
Table 2. Univariate and multivariate linear regression analysis of factors associated with minimum apparent diffusion coefficient and maximum standardized uptake value of the primary tumor

\begin{tabular}{|c|c|c|c|c|c|}
\hline \multirow[t]{2}{*}{ Variables } & \multicolumn{2}{|c|}{ Univariate analysis } & \multicolumn{3}{|c|}{ Multiple linear regression analysis } \\
\hline & $r / U$ & $\mathbf{p}$ & Coefficients & $95 \% \mathrm{Cl}$ & $\mathbf{p}$ \\
\hline \multicolumn{6}{|l|}{ Age } \\
\hline$A D C_{\min }$ & -0.405 & 0.006 & -0.105 & -0.361 to 0.152 & 0.416 \\
\hline $\mathrm{SUV}_{\max }$ & 0.340 & 0.022 & 0.136 & 0.122 to 0.394 & 0.293 \\
\hline \multicolumn{6}{|l|}{ FIGO stage } \\
\hline$A D C_{\min }$ & -0.257 & 0.088 & - & - & - \\
\hline$S U V_{\max }$ & 0.436 & 0.003 & 2.479 & 2.217 to 3.176 & 0.721 \\
\hline \multicolumn{6}{|c|}{ Non-endometrioid histology } \\
\hline$A D C_{\min }$ & 103.5 & 0.051 & - & - & - \\
\hline$S U V_{\max }$ & 129.0 & 0.209 & - & - & - \\
\hline \multicolumn{6}{|l|}{ Grade } \\
\hline$A D C_{\min }$ & -0.224 & 0.139 & - & - & - \\
\hline$S U V_{\max }$ & 0.272 & 0.071 & - & - & - \\
\hline \multicolumn{6}{|l|}{ Tumor size } \\
\hline$A D C_{\min }$ & -0.230 & 0.128 & - & - & - \\
\hline$S_{\text {SUV }}$ max & 0.488 & 0.001 & 1.269 & -0.226 to 2.765 & 0.094 \\
\hline \multicolumn{6}{|l|}{ Deep myoinvasion } \\
\hline$A D C_{\min }$ & 134.5 & 0.021 & 9.457 & 2.693 to 16.221 & 0.007 \\
\hline $\mathrm{SUV}_{\max }$ & 87.0 & 0.001 & 8.494 & 1.178 to 15.810 & 0.024 \\
\hline \multicolumn{6}{|c|}{ Lymphovascular space invasion } \\
\hline$A D C_{\min }$ & 110.5 & 0.015 & 2.758 & -3.254 to 8.769 & 0.360 \\
\hline$S U V_{\max }$ & 101.0 & 0.007 & 2.056 & -4.515 to 8.628 & 0.530 \\
\hline \multicolumn{6}{|l|}{ Cervical invasion } \\
\hline$A D C_{\min }$ & 193.0 & 0.556 & - & - & - \\
\hline$S U V_{\max }$ & 153.5 & 0.119 & - & - & - \\
\hline \multicolumn{6}{|l|}{ Adnexal invasion } \\
\hline$A D C_{\min }$ & 108.5 & 0.776 & - & - & - \\
\hline$S U V_{\max }$ & 55.5 & 0.040 & - & - & - \\
\hline \multicolumn{6}{|c|}{ Lymph node metastasis } \\
\hline$A D C_{\min }$ & 109.0 & 0.247 & - & - & - \\
\hline$S U V_{\max }$ & 84.0 & 0.057 & - & - & - \\
\hline \multicolumn{6}{|c|}{ No. of metastatic lymph nodes } \\
\hline$A D C_{\min }$ & -0.171 & 0.262 & - & - & - \\
\hline$S U V_{\max }$ & 0.295 & 0.049 & 0.502 & -0.868 to 1.871 & 0.463 \\
\hline \multicolumn{6}{|l|}{ Recurrence } \\
\hline$A D C_{\min }$ & 90.5 & 0.376 & - & - & - \\
\hline$S U V_{\max }$ & 87.0 & 0.316 & - & - & - \\
\hline \multicolumn{6}{|l|}{ Survival } \\
\hline$A D C_{\min }$ & 41.0 & 0.392 & - & - & - \\
\hline $\mathrm{SUV}_{\max }$ & 49.0 & 0.643 & - & - & - \\
\hline
\end{tabular}

ADC $\min$ : Minimum apparent diffusion coefficient, SUV ${ }_{\max }$ : Maximum standardized uptake value, r; Spearman's rho correlation coefficient, U; Mann Whitney U test statistic, CI: Confidential interval, FIGO: International Federation of Gynecology and Obstetrics. Boldface indicates statistical significance $(p<0.05)$ 
the potential factors associated with $A D C_{\text {min }}$ were age $(p=0.006)$, deep $\mathrm{Ml}(p=0.021)$, and LVSI $(p=0.015)$; the potential factors associated with $S U V_{\max }$ were age $(p=0.022)$, stage $(p=0.003)$, tumor size $(p=0.001)$, deep MI $(p=0.001)$, LVSI $(p=0.007)$ and number of metastatic LNs $(p=0.049)$. However, only the deep myometrial invasion remained to be an independent variable associated with $A D C_{\min }(p=0.007)$ as well as SUV $\max (p=0.024)$ after adjustment for other confounders in multivariate analysis. There was a significant but moderate and negative correlation between the $A D C_{\min }$ and $\mathrm{SUV}_{\max }(r=-0.518$, $\mathrm{p}<0.001)$.

Optimal cutoff values of $A D C_{\min }$ and $S U V_{\text {max }}$ for predicting deep $\mathrm{MI}$ were found to be $\leq 0.77$ (93.7\% sensitivity, $48.2 \%$ specificity, 50.0\% PPV, and 93.0\% NPV) and $>20.5$ (62.5\% sensitivity, $86.2 \%$ specificity, $71.0 \%$ PPV, and $81.0 \%$ NPV), respectively; although the comparison of two diagnostic tests revealed no statistical significance $\left[A \cup C-A D C_{\min }=0.812\right.$ (95\% Cl: 0.668-0.913), AUC-SUV $\max =0.710$ (95\% Cl: 0.5560.836 ); $p=0.266$ ], (Figure 4). Moreover, the combination of two biomarkers $\left(A D C_{\min } \leq 0.77\right.$ and $\left.S U V_{\text {max }}>20.5\right)$ failed to improve the diagnostic accuracy (56\% sensitivity, $86.2 \%$ specificity, 69.2\% PPV, and 78.1\% NPV).

\section{Discussion}

In the current study, we investigated the correlation between various clinicopathologic features and $S U V_{\text {max }}$ and $A D C_{\min }$ of the primary tumor in patients with $E C$. The study provides evidence that the depth of $\mathrm{MI}$ is the sole clinicopathologic feature independently associated with $S U V_{\max }$ as well as $A D C_{\min }$. The combination of one of these biomarkers with intraoperative frozen-section examination may offer better prediction of deep myometrial invasion, and thereby selection of patients for an extensive surgery.

Several studies have evaluated the predictors of extrauterine tumor spread in EC patients, and most studies reported age, tumor grade, myometrial invasion, LVSI, and tumor histology as potential risk factors (6). With respect to these factors, there are various suggested risk assessment models in the current literature $(10,18,19,20)$; however, the majority
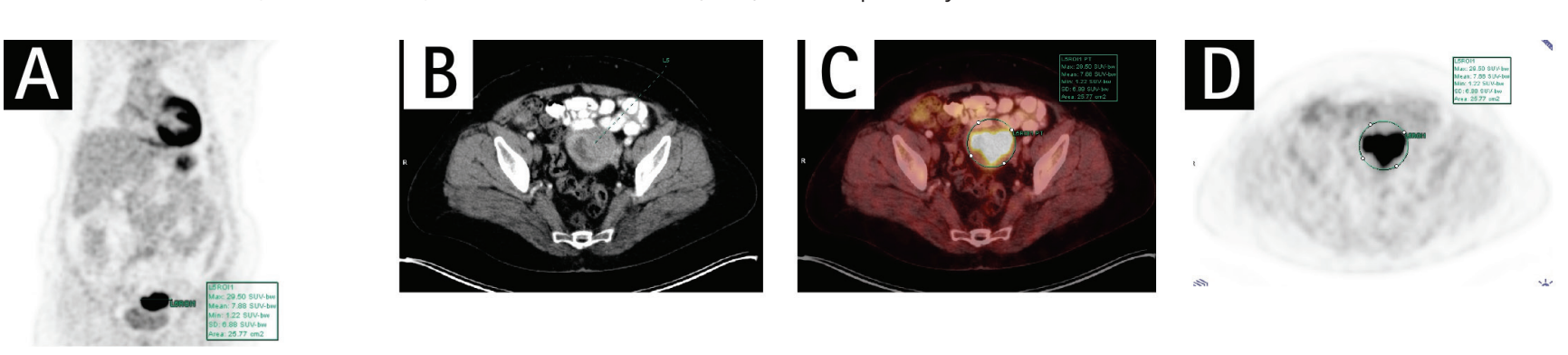

of these models are based on the results of preoperative biopsy and intraoperative frozen-section examination, which have been shown to be prone to underestimation of tumor grade and $\mathrm{MI}$ in $15 \%$ to $20 \%$ of patients $(11,21)$. Although a comprehensive staging surgery still remains the most reliable approach for determining extrauterine tumor spread, it is evident that there is a need to develop novel preoperative risk assessment strategies to avoid systematic overtreatment in patients with EC.

Emerging data indicates that $A D C_{\text {min }}$ value derived from DW-MRI and SUV max $_{\text {max }}$ derived from 18F-FDG PET/CT may have a potential role in preoperative assessment of patients with EC (14). DW-MRI can visualize the microscopic movement of extracellular water protons, which allows discrimination of tissues according to their cellularity and fluid diffusivity (22). The diffusivity can be quantified by calculating the $A D C_{\min }$ value. $S U V_{\max }$ is a measure of glucose metabolism rate, which is also correlated with the cellularity of the tissue. When compared to benign lesions, malignant tumors show higher cellularity, and thereby lower $A D C_{\min }$ and higher SUV $V_{\max }$ values $(23,24)$. Although various studies suggested a possible relationship between the $S U V_{\max }$ and $A D C_{\min }$ of the primary tumor and tumor characteristics such as grade, myometrial invasion, stage, recurrence, and survival $(13,14,25,26,27)$, uncertainty remains regarding the true magnitude and structure of these relationships as there are limited data that compare both parameters in the same study group.

In the single study investigating the relationships of $S U V_{\max }$ and $A D C_{\text {min }}$ obtained from a preoperative evaluation with 18F-FDG PET/CT and DW-MRI to clinicopathologic characteristics in patients with EC, Nakamura et al. (14) reported the data of 131 patients, with a median time to follow-up of $\sim 20$ months. The authors found that low $A D C_{\min }$ values were associated with stage 3 to 4 disease $(p<0.001)$, grade 3 tumor $(p<0.001)$, deep MI $(p=0.002)$, cervical involvement $(p=0.001), L N$ metastasis $(p=0.018)$, LVSI $(p<0.001)$, and large tumor size $(p<0.001)$. Although there was a significant and inverse correlation with $A D C_{\min }$ and $S U V_{\max }(r=-0.677, p<0.001)$, the $S U V_{\max }$ of the primary tumor was associated with disease-free and

Figure 3. Maximum standardized uptake value of the primary tumor was measured 29,50. Endometrioid type endometrial carcinoma (grade 1, International Federation of Gynecology and Obstetrics stage 2). A) Maximum intensity projection image. B) Transaxial computed tomography image. C) Transaxial positron emission tomography+computed tomography fusion image. D) Transaxial positron emission tomography image of the primary tumor 
overall survival rates while $A D C_{\text {min }}$ was not. The other study of interest relating to this issue in the literature was reported by Shih et al. (28). Although the authors used the data obtained from an integrated PET/MRI system, they similarly found a significant inverse correlation between the $S U V_{\max }$ and $A D C_{\min }$ of the primary tumor in 36 patients with EC $(r=-0.53, p=0.001)$. In that study, both SUV $\max$ and $A D C_{\min }$ were significantly associated with many prognostic factors; however, unlike the study by Nakamura et al. (14), the authors found no significant association between SUV $V_{\max }$ and tumor grade, as well as between $A D C_{\text {min }}$ and myometrial invasion, LVSI, and LN metastasis.

A significant inverse correlation between $S U V_{\max }$ and $A D C_{\min }$ was also evident in our study. Contrary to previous studies, we observed that the SUV max and $A D C_{\text {min }}$ values were only associated with the depth of $\mathrm{Ml}$ among all clinicopathologic factors. Both imaging biomarkers were comparable in their abilities to estimate deep myometrial invasion. However, combining these two biomarkers resulted in a decrease in the specificity rate and NPV. It is possible that the discrepancy between our findings and those of other researchers may be due to the differences in statistics used and sample size. While the previous studies assessed the relationships between variables by using correlational statistics only, we applied a multiple linear regression analysis to determine the independent effect of each variable. This method provided controlling for the potential confounding variables.

As with all studies, the analyses presented in this paper are not without limitations. Single-institutional cohort studies, such as this one, are inherently susceptible to referral and selection bias affecting the generalizability of findings. The small sample size of our study might have caused a

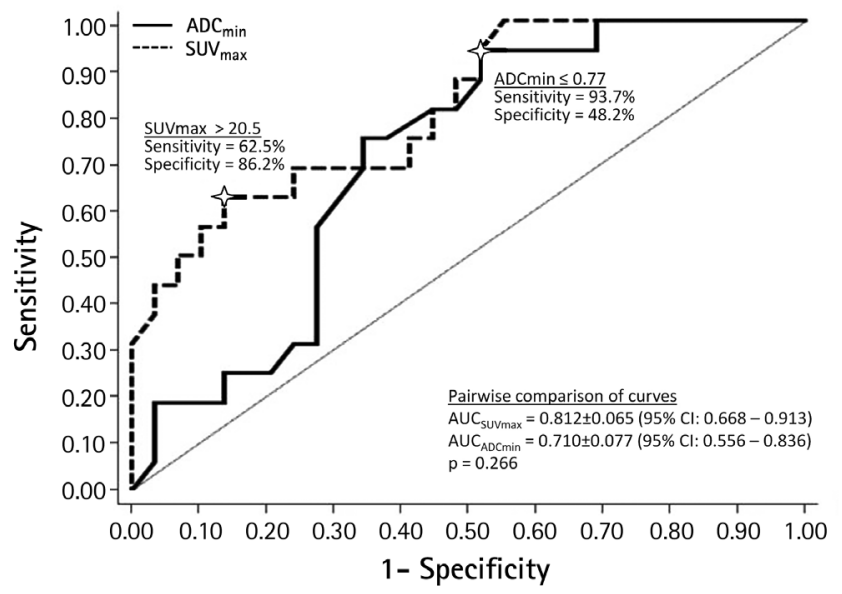

Figure 4. Receiver operating characteristic curve analysis for the diagnostic value of minimum apparent diffusion coefficient and maximum standardized uptake value of the primary tumor in predicting deep myometrial invasion

$A D C_{\text {min }}$ : Minimum apparent diffusion coefficient, SUV $V_{\text {max }}$ : Maximum standardized uptake value, Cl: Confidential interval sampling error, limiting the power in detecting associations. A relatively short median follow-up time and lack of analysis of other potential confounders, such as comorbidities, anthropometric measurements, smoking, and biochemical markers could also be considered potential limitations.

\section{Conclusion}

In conclusion, based on our results, SUV $\max$ of the primary tumor derived from $18 \mathrm{~F}-\mathrm{FDG} \mathrm{PET} / \mathrm{CT}$ and $\mathrm{ADC}$ min of the primary tumor derived from DW-MRI may have a role in predicting deep $\mathrm{Ml}$ with similar diagnostic accuracies. However, the predictive performances of both imaging biomarkers do not seem high enough to support their routine use. Furthermore, the combined use of the two tests may lead to worsening of the predictive accuracies of each biomarker. Trials with a larger cohort of patients and longer follow-up data are needed for further validation of these biomarkers.

\section{Acknowledgments}

The authors received no financial support for the research, authorship, and/or publication of this article.

The authors declare that they have no potential conflicts of interest with respect to the research, authorship, and/or publication of this article.

\section{Ethics}

Ethics Committee Approval: The study were approved by the Akdeniz University of Local Ethics Committee (Protocol number: 23.12.2015; 386), Informed Consent: Consent form was filled out by all participants.

Peer-review: Externally peer-reviewed.

\section{Authorship Contributions}

Surgical and Medical Practices: Tayfun Toptaş, Tayup Şimşek, Concept: Funda Aydın, Evrim Sürer Budak, Tayfun Toptaş, Ali Ozan Öner, Design: Funda Aydın, Evrim Sürer Budak, Tayfun Toptaş, Data Collection or Processing: Evrim Sürer Budak, Tayfun Toptaş, Ali Ozan Öner, Analysis or Interpretation: Evrim Sürer Budak, Tayfun Toptaş, Funda Aydın, Can Çevikol, Literature Search: Funda Aydın, Evrim Sürer Budak, Tayfun Toptaş, Writing: Funda Aydın, Evrim Sürer Budak, Tayfun Toptaş.

Conflict of Interest: No conflict of interest was declared by the authors.

Financial Disclosure: The authors declared that this study received no financial support.

\section{References}

1. GLOBOCAN 2012: Estimated cancer incidence, mortality and prevalence worldwide in 2012: International Agency for Research on Cancer. Available at: http://globocan.iarc.fr. Accessed 02.02.2016.

2. Siegel R, Ma J, Zou Z, Jemal A. Cancer statistics, 2014. CA Cancer J Clin 2014;64:9-29. 
3. Ueda SM, Kapp DS, Cheung MK, Shin JY, Osann K, Husain A, Teng NN, Berek JS, Chan JK. Trends in demographic and clinical characteristics in women diagnosed with corpus cancer and their potential impact on the increasing number of deaths. Am J Obstet Gynecol 2008;198:218.

4. Creasman W. Revised FIGO staging for carcinoma of the endometrium. Int J Gynaecol Obstet 2009;105:109.

5. Edge SB, Byrd DR, Compton CC. AJCC Cancer staging manual, 7th ed. New York, Springer 2010.

6. NCCN Clinical Practice Guidelines in Oncology (NCCN Guidelines). Uterine Neoplasms, Version II. 2016. Available at: http://www.nccn. org. Accessed 02.02.2016.

7. Dowdy SC, Borah BJ, Bakkum-Gamez JN, Kumar S, Weaver AL, McGree ME, Haas LR, Cliby WA, Podratz KC. Factors predictive of postoperative morbidity and cost in patients with endometrial cancer. Obstet Gynecol 2012;120:1419-1427.

8. Benedetti Panici P, Basile S, Maneschi F, Alberto Lissoni A, Signorelli M, Scambia G, Angioli R, Tateo S, Mangili G, Katsaros D, Garozzo G, Campagnutta E, Donadello N, Greggi S, Melpignano M, Raspagliesi F, Ragni N, Cormio G, Grassi R, Franchi M, Giannarell D, Fossati R, Torri V, Amoroso M, Crocè C, Mangioni C. Systematic pelvic lymphadenectomy vs. no lymphadenectomy in early-stage endometrial carcinoma: randomized clinical trial. J Natl Cancer Inst 2008;100:1707-1716.

9. ASTEC study group, Kitchener $H$, Swart AM, Qian Q, Amos C, Parmar MK. Efficacy of systematic pelvic lymphadenectomy in endometrial cancer (MRC ASTEC trial): a randomised study. Lancet 2009;373:125-136

10. Milam MR, Java J, Walker JL, Metzinger DS, Parker LP, Coleman RL; Gynecologic Oncology Group. Nodal metastasis risk in endometrioid endometrial cancer. Obstet Gynecol 2012;119:286-292.

11. Frumovitz $M$, Singh DK, Meyer L, Smith DH, Wertheim I, Resnik E, Bodurka DC. Predictors of final histology in patients with endometrial cancer. Gynecol Oncol 2004;95:463-468.

12. Antonsen $S L$, Jensen $L N$, Loft $A$, Berthelsen $A K$, Costa J, Tabor $A$, Qvist I, Hansen MR, Fisker R, Andersen ES, Sperling L, Nielsen AL, Asmussen J, Høgdall E, Fagö-Olsen CL, Christensen IJ, Nedergaard L, Jochumsen K, Høgdall C. MRI, PET/CT and ultrasound in the preoperative staging of endometrial cancer - a multicenter prospective comparative study. Gynecol Oncol 2013;128:300-308.

13. Ghooshkhanei H, Treglia G, Sabouri G, Davoodi R, Sadeghi R. Risk stratification and prognosis determination using (18)F-FDG PET imaging in endometrial cancer patients: a systematic review and meta-analysis. Gynecol Oncol 2014;132:669-676.

14. Nakamura K, Joja I, Fukushima C, Haruma T, Hayashi C, Kusumoto T, Seki N, Hongo A, Hiramatsu Y. The preoperative SUVmax is superior to $A D C$ min of the primary tumour as a predictor of disease recurrence and survival in patients with endometrial cancer. Eur J Nucl Med Mol Imaging 2013;40:52-60.

15. Silverberg SG, Kurman RJ, Nogales F, Mutter GL, Kubik-Huch RA, Tavassoli FA. Tumours of the uterine corpus. In: Tavassolli FA, Devilee P (eds). World Health Organization Classification of Tumours, Pathology \& Genetics, Tumours of the Breast and Female Genital
Organs by The International Agency for Research on Cancer (IARC). 3th ed. Geneva, Switzerland, World Health Organization/IARC, 2003;222-223.

16. Hughes G. Youden's index and the weight of evidence. Methods Inf Med 2015;54:198-199.

17. DeLong ER, DeLong DM, Clarke-Pearson DL. Comparing the areas under two or more correlated receiver operating characteristic curves: a nonparametric approach. Biometrics 1988;44:837-845.

18. Mariani A, Webb MJ, Keeney GL, Haddock MG, Calori G, Podratz KC. Low-risk corpus cancer: is lymphadenectomy or radiotherapy necessary? Am J Obstet Gynecol 2000;182:1506-1519.

19. Vargas R, Rauh-Hain JA, Clemmer J, Clark RM, Goodman A, Growdon WB, Schorge JO, Del Carmen MG, Horowitz NS, Boruta DM. Tumor size, depth of invasion, and histologic grade as prognostic factors of lymph node involvement in endometrial cancer: a SEER analysis. Gynecol Oncol 2014;133:216-220.

20. Todo $Y$, Sakuragi N, Nishida R, Yamada T, Ebina $Y$, Yamamoto R, Fujimoto $S$. Combined use of magnetic resonance imaging, CA 125 assay, histologic type, and histologic grade in the prediction of lymph node metastasis in endometrial carcinoma. Am J Obstet Gynecol 2003;188:1265-1272.

21. Daniel AG, Peters WA. Accuracy of office and operating room curettage in the grading of endometrial carcinoma. Obstet Gynecol 1988;71:612-614.

22. Bammer R. Basic principles of diffusion-weighted imaging. Eur J Radiol 2003;45:169-184.

23. Takeuchi M, Matsuzaki K, Nishitani H. Diffusion-weighted magnetic resonance imaging of endometrial cancer: differentiation from benign endometrial lesions and preoperative assessment of myometrial invasion. Acta Radiol 2009;50:947-953.

24. Hickeson M, Yun M, Matthies A, Zhuang H, Adam LE, Lacorte L, Alavi A. Use of a corrected standardized uptake value based on the lesion size on CT permits accurate characterization of lung nodules on FDG-PET. Eur J Nucl Med Mol Imaging 2002;29:1639-1647.

25. Nakamura K, Imafuku N, Nishida T, Niwa I, Joja I, Hongo A, Kodama J, Hiramatsu Y. Measurement of the minimum apparent diffusion coefficient (ADCmin) of the primary tumor and CA125 are predictive of disease recurrence for patients with endometrial cancer. Gynecol Oncol 2012;124:335-339.

26. Inoue C, Fujii S, Kaneda S, Fukunaga T, Kaminou T, Kigawa J, Harada T, Ogawa T. Correlation of apparent diffusion coefficient value with prognostic parameters of endometrioid carcinoma. J Magn Reson Imaging 2015;41:213-219.

27. Woo S, Cho JY, Kim SY, Kim SH. Histogram analysis of apparent diffusion coefficient map of diffusion-weighted MRI in endometrial cancer: a preliminary correlation study with histological grade. Acta Radiol 2014;55:1270-1277.

28. Shih IL, Yen RF, Chen CA, Chen BB, Wei SY, Chang WC, Sheu BC, Cheng WF, Tseng YH, Chen XJ, Chen CH, Wei LH, Chiang YC, Torng $\mathrm{PL}$, Yen ML, Shih TT. Standardized uptake value and apparent diffusion coefficient of endometrial cancer evaluated with integrated whole-body PET/MR: Correlation with pathological prognostic factors. J Magn Reson Imaging 2015;42:1723-1732. 